Original Research Article

\title{
Disparity in cost of oral hypoglycemic agents available in Indian market
}

\author{
Dheeraj Kumar Singh, Mukesh Kumar, Soni*
}

Department of Pharmacology, All India Institute of Medical Sciences, Patna, India

Received: 16 September 2019

Revised: 24 October 2019

Accepted: 05 November 2019

\section{*Correspondence to:}

Dr. Soni,

Email: dr.soni.rmch@gmail.com

Copyright: (C) the author(s), publisher and licensee Medip Academy. This is an openaccess article distributed under the terms of the Creative Commons Attribution NonCommercial License, which permits unrestricted noncommercial use, distribution, and reproduction in any medium, provided the original work is properly cited.

\begin{abstract}
Background: Diabetes is one of the most common non-communicable disease worldwide, of which India has been crowned with the title of "diabetes capital of the world". On an average a person spends $20 \%$ of his or her income for the treatment of diabetes per year. So, it's become very important to conduct a complete cost disparity study among oral hypoglycemic agent available in the market. Information generated from the current analysis, will be helpful to doctors in choosing the right drug for their patient and for the health sector in successfully utilizing the available resources.

Methods: The study was conducted in the department of pharmacology AIIMS, Patna 2019. Price of the drugs per tablet/capsule/vial was reviewed from "Current Index of Medical Specialties" January-April 2019 and "Drug Today" October-December, 2018 for analysis of different formulations of oral hypoglycemic agents.

Results: The cost of total 16 drugs belonging to 6 different classes, available in 38 different formulations was analyzed. Total 44 different pharmaceutical companies were involved in the manufacture of oral hypoglycemic agents. Overall glibenclamide $(5 \mathrm{mg})$ and bromocriptine $(2.5 \mathrm{mg})$ showed maximum \% price variation of 422.79 and 586.27 respectively. Dapagliflozin and canagliflozin both belonging to sodium glucose cotransporter-2 inhibitors shows minimum price variation of 9.86 and 0.9 respectively.

Conclusions: The current study shows that there is a huge price variation among oral hypoglycemic agents manufactured by different companies and government needs to take essential steps to bring about the uniformity in the price.
\end{abstract}

Keywords: Diabetes, Oral hypoglycemic agent, Price variation

\section{INTRODUCTION}

Pharmacoeconomics plays a vital role in adherence of patients to treatment of non-communicable diseases (NCDs), as in non-communicable disease treatment is going to be lifelong. According to WHO NCDs kill 41 million people each year, equivalent to $71 \%$ of all deaths globally. ${ }^{1}$ Cardiovascular diseases account for most NCD deaths, or 17.9 million people annually, followed by cancers (9.0 million), respiratory diseases (3.9 million), and diabetes (1.6 million). ${ }^{2} 80 \%$ of all premature NCD deaths occurring worldwide accounts to these four main group of diseases. ${ }^{3}$ Out of many factors determining the mortality and morbidity in NCDs, high cost is one of the most important reason for non-compliance of the patient leading to poor management of NCDs. In developing country like India cost of medicine is centre of concern for both physician and patient.

Diabetes is one of the most common non-communicable disease world wide of which India has been crowned with the title of "Diabetes capital of the world". 4 According to WHO the number of adults with type 2 diabetes is expected to rise by more than a fifth from 406 million in 2018 to 511 million in 2030 worldwide of which over half of them will be living in just three countries- China (130 million), India (98 million), and the US (32 million). ${ }^{5,6}$

In 2015, India had 69.2 million people living with diabetes alone according to WHO. Prevalence of diabetes is $20 \%$ in urban and $10 \%$ in rural population of India. ${ }^{7}$ In developing country like India where a majority belong to 
low socio economic class has frequently have to make option between buying food or medicine due to high drug cost and limited resources. On an average a person spends $20 \%$ of his or her income for the treatment of diabetes per year. ${ }^{8}$

Pharmaceutical industry is India has grown at tremendous rate in last few decades. Currently India occupies the most respectful position in world by producing generic drug at largest quantity. Apart from these, Indian pharmaceutical sector industry supplies over 50 per cent of global demand for various vaccines, 40 per cent of generic demand in the US and 25 per cent of all medicine in UK. ${ }^{9}$ In India metformin, glibenclamide and acarbose are the most frequently used drugs in primary health care clinic for treatment of diabetes. ${ }^{10}$ Diabetes prevalence and incidence is increasing rapidly and so is the economic burden. So, it become very important to conduct a complete cost disparity studies among oral hypoglycaemic agent available in market. Information generated from the analysis study will be helpful to doctors in choosing right drug for their patient and for the health sector in successfully utilizing the available resources.

\section{Objectives}

The objective of the present study was to find the cost of single oral anti-diabetics of different brand names in Indian market and to analyze the difference in cost of different brands for the same dosage of same active drug by calculating percentage variation of cost.

\section{METHODS}

The study was conducted in department of pharmacology AIIMS, Patna 2019. Price of the drugs per tablet/capsule/vial were reviewed from "Current Index of Medical Specialties" January-April 2019, "Drug Today " October-December, 2018 and website http://medlineindia.com for analysis of different formulations of oral hypoglycemic agents.

\section{Inclusion criteria}

The retail cost of a particular drug being manufactured by different companies, in the same strength, number and dosage forms was compared.

\section{Exclusion criteria}

The drug formulation manufactured by only one company was excluded from the study.

\section{Statistical analysis}

Percentage price variation was calculated by

$\%$ Price variation $=\frac{\text { Maximum price-Minimum price }}{\text { Minimum price }} \times 100$.

\section{RESULTS}

The cost of total 16 drugs belonging to 6 different classes, available in 38 different formulations was analyzed. Total 44 different pharmaceutical companies were involved in the manufacture of oral hypoglycaemic agents. Overall glibenclamide $(5 \mathrm{mg})$ and bromocriptine $(2.5 \mathrm{mg})$ showed maximum \% price variation of 422.79 and 586.27 respectively. Dapagliflozin and canagliflozin both belonging to sodium-glucose cotransporter-2 (SGLT-2) inhibitors shows minimum price variation of 9.86 and 0.92 respectively. The percentage price variation among sulphonylureas class is glibenclamide $(2.5$ $\mathrm{mg}) 112.7 \%$, glibenclamide $(5 \mathrm{mg}) 422.79 \%$, glipizide (2.5 mg) $70.97 \%$, glipizide $(5 \mathrm{mg}) 165.01 \%$, glipizide (10 $\mathrm{mg}) 19.79 \%$, gliclazide $(30 \mathrm{mg}) 48.81 \%$, gliclazide (40 $\mathrm{mg}) 233.33 \%$, gliclazide $(60 \mathrm{mg}) 52.78 \%$, gliclazide $(80$ mg) $164 \%$, glimepiride (1 mg) $618.18 \%$, glimepiride (2 $\mathrm{mg}) 576.70 \%$, glimepiride (3 mg) $265.55 \%$, glimepiride (4 mg) $381.90 \%$.

Meglitinide class is repaglinide (0.5 mg) 106.9\%, repaglinide (1 mg) 41.28\%, repaglinide (2 mg) $78.85 \%$, nateglinide $(60 \mathrm{mg}) 50 \%$, nateglinide $(120 \mathrm{mg}) 60 \%$. Dipeptidyl peptidase 4 (DPP-4) are sitagliptine $(25 \mathrm{mg})$ $0 \%$, sitagliptine $(50 \mathrm{mg}) 42.84 \%$, sitagliptine $(100 \mathrm{mg})$ $42.86 \%$, vildagliptine (50) $0 \%$, tenegliptine (20 mg) $99.92 \%$, biguanide class are metformin $(250 \mathrm{mg}) 82.03 \%$, metformin (500 mg) 335.33\%, metformin (850 mg) $132.56 \%$, metformin (1000 mg) $106.35 \%$, metformin (30 $\mathrm{mg}) 247.83 \%$, alpha glucosidase inhibitor are acarbose (25 mg) $88.39 \%$, acarbose $(50 \mathrm{mg}) 74.03 \%$, voglibose (0.2 mg) $120.59 \%$, voglibose $(0.3 \mathrm{mg}) 233.33 \%$, miglitol (25 mg) $81.35 \%$, miglitol (50 mg) $126.67 \%$, SGLT-2 inhibitors are dapagliflozin $(10 \mathrm{mg}) 9.86 \%$, canagliflozin (100 mg) 0.92\%. Bromocriptine (1.25 mg) $160.51 \%$, bromocriptine $(2.5 \mathrm{mg}) 586.27 \%$.

Table 1: Price variation among sulfonylureas group of drug.

\begin{tabular}{|lllllll|}
\hline \multirow{2}{*}{ Drug } & Formulation & Dose & $\begin{array}{l}\text { No. of } \\
\text { brands }\end{array}$ & $\begin{array}{l}\text { Minimum } \\
\text { cost }\end{array}$ & $\begin{array}{l}\text { Maximum } \\
\text { cost }\end{array}$ & \% of price variation \\
\hline \multirow{2}{*}{ Glibenclamide } & $\mathrm{Tab}$ & $2.5 \mathrm{mg}$ & 6 & 2.82 & 6 & 112.77 \\
\cline { 2 - 7 } & $\mathrm{Tab}$ & $5 \mathrm{mg}$ & 10 & 3.73 & 19.5 & 422.79 \\
\hline \multirow{3}{*}{ Glipizide } & $\mathrm{Tab}$ & $2.5 \mathrm{mg}$ & 5 & 3.1 & 5.3 & 70.97 \\
& $\mathrm{Tab}$ & $5 \mathrm{mg}$ & 14 & 4.83 & 12.8 & 165.01 \\
\hline & $\mathrm{Tab}$ & $10 \mathrm{mg}$ & 3 & 19 & 22.76 & 19.79 \\
\hline Gliclazide & $\mathrm{Tab}$ & $30 \mathrm{mg}$ & 8 & 21 & 31.25 & 48.81 \\
\hline
\end{tabular}

Continued. 


\begin{tabular}{|lllllll|}
\hline Drug & Formulation & Dose & $\begin{array}{l}\text { No. of } \\
\text { brands }\end{array}$ & $\begin{array}{l}\text { Minimum } \\
\text { cost }\end{array}$ & $\begin{array}{l}\text { Maximum } \\
\text { cost }\end{array}$ & \% of price variation \\
\hline \multirow{5}{*}{ Glimiperide } & Tab & $40 \mathrm{mg}$ & 17 & 15 & 50 & 233.33 \\
\cline { 2 - 7 } & Tab & $60 \mathrm{mg}$ & 6 & 36 & 55 & 52.78 \\
\cline { 2 - 7 } & Tab & $80 \mathrm{mg}$ & 31 & 19.5 & 51.48 & 164.00 \\
\hline & Tab & $1 \mathrm{mg}$ & 32 & 11 & 79 & 618.18 \\
\cline { 2 - 7 } & Tab & $2 \mathrm{mg}$ & 36 & 15.28 & 103.4 & 576.70 \\
\cline { 2 - 7 } & Tab & $3 \mathrm{mg}$ & 9 & 35.5 & 129.77 & 265.55 \\
\cline { 2 - 7 } & Tab & $4 \mathrm{mg}$ & 13 & 22.93 & 110.5 & 381.90 \\
\hline
\end{tabular}

Table 2: Price variation among meglitinide group of drug.

\begin{tabular}{|lllllll|} 
Drug & Formulation & Dose & $\begin{array}{l}\text { No. of } \\
\text { brands }\end{array}$ & $\begin{array}{l}\text { Minimum } \\
\text { cost }\end{array}$ & $\begin{array}{l}\text { Maximum } \\
\text { cost }\end{array}$ & \% of price variation \\
\hline Meglitinides & & & & & & \\
\hline \multirow{2}{*}{ Repaglinide } & Tab & $0.5 \mathrm{mg}$ & 5 & 29 & 60 & 106.90 \\
\cline { 2 - 7 } & $\mathrm{Tab}$ & $1 \mathrm{mg}$ & 5 & 98.6 & 139.3 & 41.28 \\
\cline { 2 - 7 } & $\mathrm{Tab}$ & $2 \mathrm{mg}$ & 4 & 78 & 139.5 & 78.85 \\
\hline \multirow{2}{*}{ Nateglinide } & $\mathrm{Tab}$ & $60 \mathrm{mg}$ & 3 & 30 & 45 & 50.00 \\
\cline { 2 - 7 } & Tab & $120 \mathrm{mg}$ & 3 & 50 & 80 & 60.00 \\
\hline
\end{tabular}

Table 3: Price variation DPP-4 inhibitors among DPP-4 inhibitors group of drug.

\begin{tabular}{|lllllll|}
\hline Drug & Formulation & Dose & $\begin{array}{l}\text { No. of } \\
\text { brands }\end{array}$ & $\begin{array}{l}\text { Minimum } \\
\text { cost }\end{array}$ & $\begin{array}{l}\text { Maximum } \\
\text { cost }\end{array}$ & \% of price variation \\
\hline DPP-4 inhibitors & & & & & & \\
\hline \multirow{3}{*}{ Sitagliptine } & $\mathrm{Tab}$ & $25 \mathrm{mg}$ & 2 & 427.1 & 427.1 & 0.00 \\
\cline { 2 - 7 } & $\mathrm{Tab}$ & $50 \mathrm{mg}$ & 2 & 299 & 427.1 & 42.84 \\
\cline { 2 - 7 } & $\mathrm{Tab}$ & $100 \mathrm{mg}$ & 3 & 315 & 450 & 42.86 \\
\hline Vildagliptine & $\mathrm{Tab}$ & $50 \mathrm{mg}$ & 3 & 192.85 & 192.85 & 0.00 \\
\hline Teneligliptine & $\mathrm{Tab}$ & $20 \mathrm{mg}$ & 12 & 59.9 & 119.75 & 99.92 \\
\hline
\end{tabular}

Table 4: Price variation among biguanide group of drug.

\begin{tabular}{|lllllll|}
\hline Drug & Formulation & Dose & $\begin{array}{l}\text { No. of } \\
\text { brands }\end{array}$ & $\begin{array}{l}\text { Minimum } \\
\text { cost }\end{array}$ & Maximum cost & $\begin{array}{l}\text { \% of price } \\
\text { variation }\end{array}$ \\
\hline Biguanide & & & & & & \\
\hline \multirow{3}{*}{ Metformin } & Tab & $250 \mathrm{mg}$ & 6 & 4.34 & 7.9 & 82.03 \\
\cline { 2 - 7 } & Tab & $500 \mathrm{mg}$ & 44 & 6 & 26.12 & 335.33 \\
\cline { 2 - 7 } & $\mathrm{Tab}$ & $850 \mathrm{mg}$ & 13 & 10.32 & 24 & 132.56 \\
\cline { 2 - 7 } & Tab & $1000 \mathrm{mg}$ & 19 & 18.9 & 39 & 106.35 \\
\cline { 2 - 7 } & Tab & & 29 & 23 & 80 & 247.83 \\
\hline
\end{tabular}

Table 5: Price variation among alpha glucosidase inhibitor group of drug.

\begin{tabular}{|lllllll|}
\hline Drug & Formulation & Dose & $\begin{array}{l}\text { No. of } \\
\text { brands }\end{array}$ & $\begin{array}{l}\text { Minimum } \\
\text { cost }\end{array}$ & Maximum cost & $\begin{array}{l}\text { \% of price } \\
\text { variation }\end{array}$ \\
\hline Alpha glucosidase inhibitors & & & & & & \\
\hline \multirow{2}{*}{ Acarbose } & Tab & $25 \mathrm{mg}$ & 15 & 36.36 & 68.5 & 88.39 \\
\cline { 2 - 7 } & Tab & $50 \mathrm{mg}$ & 16 & 38.5 & 67 & 74.03 \\
\hline \multirow{2}{*}{ Voglibose } & Tab & $0.2 \mathrm{mg}$ & 32 & 34 & 75 & 120.59 \\
\cline { 2 - 7 } Miglitol & $\mathrm{Tab}$ & $0.3 \mathrm{mg}$ & 34 & 30 & 100 & 233.33 \\
\cline { 2 - 7 } & $\mathrm{Tab}$ & $25 \mathrm{mg}$ & 6 & 63 & 114.25 & 81.35 \\
\hline
\end{tabular}


Table 6: Price variation among SGLT-2 inhibitors group of drug.

\begin{tabular}{|c|c|c|c|c|c|c|}
\hline Drug & Formulation & Dose & $\begin{array}{l}\text { No. of } \\
\text { brands }\end{array}$ & $\begin{array}{l}\text { Minimum } \\
\text { cost }\end{array}$ & Maximum cost & $\begin{array}{l}\% \text { of price } \\
\text { variation }\end{array}$ \\
\hline \multicolumn{7}{|c|}{ SGLT-2 inhibitors } \\
\hline Dapagliflozin & Tab & $10 \mathrm{mg}$ & 3 & 730 & 802 & 9.86 \\
\hline Canagliflozin & Tab & $100 \mathrm{mg}$ & 3 & 545 & 550 & 0.92 \\
\hline
\end{tabular}

Table 7: Price variation among bromocriptine.

\begin{tabular}{|lllllll|}
\hline \multirow{2}{*}{ Drug } & Formulation & Dose & $\begin{array}{l}\text { No. of } \\
\text { brands }\end{array}$ & $\begin{array}{l}\text { Minimum } \\
\text { cost }\end{array}$ & Maximum cost & $\begin{array}{l}\text { \% of price } \\
\text { variation }\end{array}$ \\
\hline \multirow{2}{*}{ Bromocriptine } & $\mathrm{Tab}$ & $1.25 \mathrm{mg}$ & 10 & 39.5 & 102.9 & 160.51 \\
\cline { 2 - 7 } & $\mathrm{Tab}$ & $2.5 \mathrm{mg}$ & 18 & 61.2 & 420 & 586.27 \\
\hline
\end{tabular}

\section{DISCUSSION}

Currently very few studies are available in Indian scenario, which compares the cost of drugs of different brands in oral hypoglycaemic agents. Indian market is predominantly a branded generic market i.e., more than one company sells a particular drug under different brand names apart from innovator company. ${ }^{9}$ This scenario lead to greater price variation among drug marketed in India. Out of 6 different classes of drug we have studied which are commonly prescribed, percentage price variation is fairly wide leading to unfair burden on consumer. In such a scenario it is prudent to re-evaluate the costing mechanism and regulation of drug price variation by concerned agencies. Studies have shown that physician is more efficient in reducing the economic burden over patients if comparative drug price manual is provided to every physician in his outpatient department. ${ }^{11}$

\section{CONCLUSION}

Pharmacoeconomic represent another obstacle to the availability of medicine. It is often referred to as "fourth hurdle", as cost effective techniques is being added to the 3 traditional criteria for licensing- efficacy, safety and quality of manufacture. On the other hand pharmacoeconomics study also gives manufacturers the opportunity to demonstrate the cost effectiveness of their product. However, the current trend shows less economic analysis study has been done and included in decision making procedure. The current study shows that there is huge price variation among oral hypoglycemic agents manufactured by different companies and government needs to take essential steps to bring about the uniformity in the price.

\section{Funding: No funding sources}

Conflict of interest: None declared

Ethical approval: The study was approved by the Institutional Ethics Committee

\section{REFERENCES}

1. Murray CJ, Lopez AD. The global burden of disease: a comprehensive assessment of mortality and disability from diseases, injuries, and risk factors in 1990 and projected to 2020: summary. In: Murray CJL, Lopez AD. World Health Organization; 1997.

2. Zhang YT. Editorial Health Engineering: Convergence Transforming Reactive Medicine to Proactive Healthcare. IEEE Reviews in Biomed Engineer. 2018;11:1.

3. World Health Organization. The global burden of disease: 2004 update.

4. Joshi SR, Parikh RM. India; the diabetes capital of the world: Now heading towards hypertension. J Assoc Physici India. 2007;55:323.

5. Hardman AE, Stensel DJ. Physical activity and health: the evidence explained. 2nd ed. USA: Routledge; 2009.

6. Kashyap AK, Stein JC. What do a million observations on banks say about the transmission of monetary policy? Am Economic Review. 2000;90(3):407-28.

7. Unnikrishnan R, Anjana RM, Mohan V. Diabetes mellitus and its complications in India. Nature Reviews Endocrinol. 2016;12(6):357.

8. Khowaja LA, Khuwaja AK, Cosgrove P. Cost of diabetes care in out-patient clinics of Karachi, Pakistan. BMC Health Services Res. 2007;7(1):189.

9. Greene W. The emergence of India's pharmaceutical industry and implications for the US generic drug market. U.S. Washington, USA: International Trade Commission; 2007-05.

10. Reece EA, Leguizamón G, Wiznitzer A. Gestational diabetes: the need for a common ground. The Lancet. 2009;373(9677):1789-97.

11. Drummond M. Pharmacoeconomics: friend or foe? Ann Rheumatic Dis. 2006;65(S3):44-7.

Cite this article as: Singh DK, Kumar M, Soni. Disparity in cost of oral hypoglycemic agents available in Indian market. Int $\mathrm{J}$ Basic Clin Pharmacol 2019;8:2631-4. 